УДК 343.98:351.741

DOI https://doi.org/10.32849/2663-5313/2020.9.30

Свген Войтович,

ад’юнкт кафедри криміналістики та судової медицини

Національної академї внутрішніх справ України

\title{
СПОСІБ ВЧИНЕННЯ КРИМІНАЛЬНИХ ПРАВОПОРУШЕНЬ, ПОВ'ЯЗАНИХ ІЗ НАСИЛЬНИЦЬКИМ ЗНИКНЕННЯМ ЛЮДИНИ
}

У статті розкриваються способи вчинення насильницького зникнення людини як багатоетапна злочинна операчія. Обгрунтовано, що способи вчинення дій, що спрямовані на насильницьке захоплення людини, досить різноманітні і містять у собі підготовчі заходи до вчинення злочину, дї співучасників під час захоплення, безпосередньо після нього й у проиесі наступного утримання потерпілого, а також з приховування слідів злочину. Реалізачія кожного подальшого етапу підпорядкована певній послідовності та єдиній меті, зміст якої виражається у вимогах, які висуваються злочиниями. Виокремлені типові моделі способу вчинення насильницького зникнення людини, яке складається з таких етапів: пошук «об'єкта викрадення» $i$ збір інформаиї про нього; розробка плану зникнення, розподіл ролей між викрадачами, підготовка спечіальних засобів і приміщення для наступного утримання потерпілого; напад і вилучення викраденого з природного мікросоціального середовища (захоплення); переміщення його до місия постійного або тимчасового утримання; утримання викраденого (як правило, у спещіально підготовленому для ивого приміщенні); пред'явлення вимог близьким потерпіло$2 о$ (або йому самому), які є необхідною умовою для його звільнення; одержання викупу $і$ звільнення викраденого (якщо викрадення було вчинене з метою одержання викупу); приховування слідів злочину. Наголошено, що позбавлення особи волі в будь-якій формі, тобто порушення права особи на свободу та особисту недоторканість, становить собою обов'язковий елемент насильницького зникнення. Порушення даного права як складовий елемент злочину насильницького зникнення є найменш дискусійним порівняно, наприклад, з порушенням права не піддаватися катуванням або іншим видам нелюдського поводження. Зроблено висновок, що виділення етапів насильнииького зникнення людини у криміналістичному аспекті має важливе значення, тому що кожен із цих етапів й різне їх сполучення мають якісні та кількісні ознаки, що забезпечують розробку і вибір прийомів, засобів $і$ методів, спрямованих не тільки на виявлення й розслідування иих злочинів, але й на запобігання їм. Знання і розуміння етапів учинення таких злочинів дозволяє встановити обставини їх вчинення, коло причетних до їх вчинення осіб, залишені сліди тощо.

Ключові слова: спосіб вчинення, досудове розслідування, напад, захоплення, приховування.

Постановка проблеми. Спосіб вчинення злочину є центральним елементом криміналістичної характеристики насильницького зникнення людини. Інформація про спосіб вчинення насильницького зникнення людини виступає основою для: висування версій; планування та організації розслідування; вибору оптимального шляху розслідування; прогнозування механізму вчинення злочину; розробки заходів запобігання.

Можна констатувати, що складна система дій $з$ підготовки та реалізації злочинного наміру, приховання його наслідків спостерігається у разі вчинення більшості злочинів міжнародного характеру й пов'язана з реалізацією злочинної діяльності на території як України, так й іноземних держав. Способи вчинення злочинів міжнародного характеру можуть виражатися у різноманітних діях, перш за все зумовлених об'єктивною сто- роною відповідного злочину, ознаки котрої визначені міжнародним та національним законодавством [1, с. 106-107].

Мета статті - розкрити способи вчинення насильницького зникнення людини як багатоетапної злочинної операції.

Виклад основного матеріалу. Виходячи 3 тексту ст. 146-1 КК, можна зробити висновок, що з об'єктивної сторони розглядуваний злочин може виражатися у таких формах: 1) арешт, затримання, викрадення або позбавлення волі людини в будь-якій іншій формі, поєднані $з$ подальшою відмовою визнати факт таких дій; 2) позбавлення волі людини, поєднане з подальшим приховуванням даних про долю такої людини чи місце iï перебування; 3) видання наказу чи розпорядження про позбавлення волі людини, або про відмову визнати факт такого позбав- 
лення волі, або про приховування даних про долю такої людини чи іï місце перебування; 4) невжиття керівником, якому стало відомо про вчинення його підлеглими позбавлення волі людини, заходів для його припинення, поєднане 3 неповідомленням компетентних органів про цей злочин; 5) неповідомлення компетентних органів про злочин керівником, якому стало відомо про вчинене його підлеглими позбавлення волі людині, поєднане 3 подальшою відмовою визнати факт такого позбавлення волі або приховуванням даних про долю такої людини чи іï місце перебування [2, с. $512 ; 3$, с. 438].

Не вдаючись до детального аналізу, зауважимо, що у широкому значенні арешт характеризується ознаками, які властиві усім видам покарань, тобто: є заходом державного примусу; призначається: від імені держави і виключно вироком суду тій особі, яка визнана винною у вчиненні злочину, за вчинення саме злочину; полягає у передбаченому КК обмеженні прав і свобод засудженого (причому автор вважає, що вказану ознаку необхідно розглядати виключно у ракурсі правового статусу засудженого); тягне за собою судимість. Арешт у вузькому значенні характеризується такими специфічними ознаками, як: особливості змісту (лімітація волі, що здійснюється шляхом пригнічення рефлексу особистої свободи у засудженого за допомогою його фізичної ізоляції); спеціально встановлене місце відбування (арештний дім); режим підвищеної суворості (який проявляється у значній кількості правообмежень, навіть порівняно 3 найсуворішим видом покарання - позбавленням волі); короткочасний строк покарання [4, c.5].

Арешт є заходом державного примусу, що застосовується за обвинувальним вироком суду до особи, винної у вчиненні злочину, і полягає у встановленні для неї в процесі виконання та відбування покарання специфічного правового статусу (обов'язків, прав (їх обмежень) та законних інтересів) $[5$, с. 119$]$.

Позбавлення особи волі в будь-якій формі, тобто порушення права особи на свободу та особисту недоторканість, становить собою обов'язковий елемент насильницького зникнення. Порушення даного права як складовий елемент злочину насильницького зникнення $є$ найменш дискусійним порівняно, наприклад, 3 порушенням права не піддаватися катуванням або іншим видам нелюдського поводження.

У ст. 3 Європейської конвенції 1950 р. гарантується право кожної особи не піддаватися катуванням та іншим жорстоким нелюдським, або таким, що принижують гідність, поводженням або покаранням. У контексті актів насильницького зникнення Європейський Суд 3 прав людини (далі - ССПЛ) підтримує більш консервативний підхід, визначаючи, що насильницьке зникнення становить собою одну з форм незаконного позбавлення волі. ЄСПЛ визначав порушення ст. 3 в контексті актів насильницького зникнення лише за наявності достатньої кількості доказів щодо застосування катувань або інших видів нелюдського поводження. У рішенні у справі Akdeniz and Others v. Turkey ССПЛ постановив порушення даного права, оскільки зниклі особи утримувалися у нелюдських умовах, мали місце тортури. Крім того, вказані особи страждали не лише від тортур, але й від страху перед невідомістю і перед майбутнім. Крім того, ЄСПЛ зазначив таке: «Процесуальні зобов'язання були виокремлені з Конвенції в різноманітних контекстах, коли це було необхідно для забезпечення того, щоб гарантовані нею права були не теоретичними та ілюзорними, а реалізованими та ефективними [6, с. 87].

Відповідно до визначення, що міститься в преамбулі до Декларації, насильницькі зникнення розглядаються як такі, тільки якщо вони здійснюються представниками держави або приватними особами чи організованими групами, наприклад напіввійськовими групами (організовані групи, до озброєння, навчання або підтримки яких реально причетна регулярна армія), що діють від імені, за прямої або непрямої підтримки, з дозволу або згоди державного органу влади. Тому не варто брати до уваги випадки, коли вони стосуються осіб або груп, що не підпадають під вищезгадані категорії, таких як терористичні або повстанські рухи, за якими не стоїть жодна держава і які ведуть боротьбу з урядом на його власній території. Ця відмінність випливає з принципу, згідно з яким держави зобов'язані розслідувати дії, порівнювані за своїм характером 3 насильницькими зникненнями, коли вони здійснюються недержавними суб'єктами, і карати за них. Відповідальність держави за насильницькі зникнення зберігається незалежно від зміни уряду, навіть якщо новий уряд демонструє більшу повагу до прав людини порівняно з урядом, що перебував при владі на момент, коли зникнення мали місце.

Для визначення акту насильницького зникнення варто виходити з того, що одним iз наслідків злочину є залишення жертви поза захистом закону. Тому необхідно розглядати випадки насильницького зникнення, не вимагаючи того, щоб інформація, що повідомляється джерелом, відбивала або навіть припускала справжній намір винної особи 
поставити жертву поза захистом закону. Крім того, акт насильницького зникнення може початися після незаконного затримання або після спочатку законного арешту чи затримання. Таким чином, захист жертви від насильницького зникнення має бути ефективним починаючи з акту позбавлення волі, незалежно від форми такого позбавлення волі, і не повинен обмежуватися випадками незаконного позбавлення волі.

Нарешті, затримання, за яким іде позасудова страта, $\epsilon$ насильницьким зникненням у власному значенні слова, якщо таке затримання було зроблене урядовими представниками якої-небудь ланки або рівня, організованими групами чи приватними особами, що діють від імені уряду, за його прямої або непрямої підтримки, з його дозволу або згоди, і якщо після затримання або навіть після страти державні посадовці відмовляються повідомляти про долю або місцезнаходження такої особи чи відмовляються взагалі визнати факт здійснення відповідного діяння.

Хоча затримання уповноваженою службовою особою у кримінальній процесуальній діяльності України є підвидом затримання особи - самостійного інституту кримінального процесуального права, міжгалузевим і складним за своєю структурою правовим явищем та розглядається у вузькому розумінні як фізичне захоплення особи та її доставлення до компетентного органу чи посадової особи для подальшого прийняття рішення (так зване «фактичне затримання» $[7$, с. 527]) та у широкому розумінні - як діяльність (комплекс дій) відповідних державних органів і посадових осіб від моменту фізичного захоплення особи до іiї звільнення або обрання запобіжного заходу у вигляді тримання під вартою.

Доводиться констатувати, що у чинному КПК України нормативному врегулюванню звільнення затриманої особи не приділено належної уваги. Так, у статтях 202, 206, 211, 212 КПК України йдеться про звільнення затриманого, однак ні підстави, ні процесуальний порядок прийняття такого рішення уповноваженими особами законом чітко не визначені [8]. Зазначені обставини, безперечно, не сприяють однаковому та правильному застосуванню законодавства у цій частині, що нерідко призводить до слідчих і судових помилок, які тягнуть за собою порушення прав, свобод і законних інтересів особи [9, с. 174].

Допускаючи у випадках нагальної необхідності запобігти злочину або припинити його застосування тримання особи під вартою як тимчасового запобіжного заходу, Конституція України встановлює необхід- ність судової перевірки обгрунтованості такого застосування протягом 72 годин. Затримана особа негайно звільняється, якщо протягом 72 годин 3 моменту затримання їй не вручено вмотивованого рішення суду про тримання під вартою (ч. 3 ст. 29 Конституції України) [10].

Конвенцією про захист прав людини і основоположних свобод $(1950$ р.) закріплено положення, відповідно до якого кожен, кого позбавлено свободи внаслідок арешту або тримання під вартою, має право ініціювати провадження, в ході якого суд без зволікання встановлює законність затримання і приймає рішення про звільнення, якщо затримання є незаконним (ч. 4 ст. 5).

Отже, не менш важливе значення, ніж законне та обгрунтоване застосування затримання уповноваженою службовою особою без ухвали слідчого судді, суду, має своєчасне, законне та обгрунтоване звільнення затриманого з-під варти.

Як відомо, законність та обгрунтованість будь-якого процесуального акту обумовлюється дотриманням вимог закону в частині підстав і процесуального порядку його здійснення та оформлення.

Звільнення затриманого є тим процесуальним актом, який, поряд із самим затриманням, також повинен відповідати вимогам законності та обгрунтованості. Орієнтуючись на положення ст. 370 КПК України (щодо законності, обгрунтованості та вмотивованості судового рішення), можна стверджувати, що рішення щодо звільнення затриманого буде законним за умови його прийняття компетентною особою згідно 3 нормами матеріального права 3 дотриманням вимог, передбачених КПК України. Обгрунтованим рішення щодо звільнення затриманого буде за умови його прийняття на підставі об'єктивно з'ясованих обставин, які підтверджені належними, допустимими, достовірними та достатніми доказами.

Системний аналіз положень вищезазначених статей КПК України дає підстави для висновку, що уповноваженими особами прийняття рішення щодо звільнення затриманого є слідчий суддя (статті 202, 206), слідчий, прокурор (ст. 211), особа, відповідальна за перебування затриманих у підрозділі органу досудового розслідування (ст. 212).

Відповідно до ст. 211 КПК України затримання особи без ухвали слідчого судді, суду не може перевищувати 72 годин з моменту затримання, тобто з моменту, коли згідно зі ст. 209 КПК України особа силою або через підкорення наказу змушена залишатися поряд з уповноваженою службовою особою чи в приміщенні, визна- 
ченому уповноваженою службовою особою. При цьому положення ч. 2 ст. 211 КПК України зобов'язує слідчого, прокурора не пізніше 60 годин з моменту затримання або звільнити особу, або доставити їі до суду для розгляду клопотання про обрання стосовно неї запобіжного заходу.

Таким чином, слідчий, прокурор є суб'єктами прийняття рішення про звільнення затриманого в усіх випадках, коли до закінчення 60-годинного строку з моменту затримання вони не звернулись із клопотанням до слідчого судді про обрання стосовно затриманого запобіжного заходу.

Особа, відповідальна за перебування затриманих, відповідно до п. 3 ч. 2 ст. 212 КПК України зобов'язана звільнити затриманого негайно після зникнення підстави для затримання або спливу строку для затримання, передбаченого ст. 211 КПК України.

Затримання уповноваженою службовою особою, як вид затримання без ухвали слідчого судді, суду, має бути повно та системно врегульоване у відповідній групі кримінальних процесуальних норм. Однак у статтях 208-213 КПК України відсутнє завершене, системне викладення положень, які б регулювали не тільки початок і перебіг затримання, а і його завершення, тобто звільнення затриманого чи обрання стосовно нього запобіжного заходу. У цьому аспекті більш вдалою видається редакція ст. 106 КПК України 1960 року, ч. 6 якої містила перелік альтернативних рішень і дій органу дізнання (слідчого, прокурора), якими завершується процедура затримання.

У чинному КПК України фактично відсутне нормативне врегулювання процесуального порядку звільнення затриманого, що, природно, викликає ряд запитань. Так, чи повинен слідчий суддя, ухвалюючи рішення про обрання стосовно підозрюваного, який є затриманим, запобіжного заходу, не пов'язаного з триманням під вартою, формулювати у своїй ухвалі рішення про звільнення затриманого? У статтях 179-182, 196, 202, 206 КПК України відповіді на це запитання немає. Відповідно, якщо таке рішення слідчим суддею в ухвалі не сформульоване, хто і в якому порядку повинен звільняти затриманого у випадках, встановлених ч. 1-4 ст. 202 КПК України? Яким є процесуальний порядок звільнення затриманого особою, відповідальною за перебування затриманих? Які документи при цьому вона повинна складати?

Способи викрадення людей досить різноманітні і містять у собі підготовчі заходи до вчинення злочину, дії співучасників у ході захоплення, безпосередньо після нього й у процесі наступного утримання потерпілого, а також стосовно приховування слідів злочину [11, с. 38].

Для того, щоб краще зрозуміти сутність розглядуваного виду злочинів, викрадення людини варто розглядати як багатоетапну злочинну операцію. Це досить складний процес, який навіть у спрощеному вигляді має налічувати декілька етапів діяльності злочинної групи. Реалізація кожного подальшого етапу злочинної діяльності підпорядкована певній послідовності та єдиній меті, зміст якої виражається у вимогах, які висуваються злочинцями.

Типова модель способу вчинення викрадення людей, на наш погляд, складається з таких етапів:

1) пошук «об'єкта викрадення» і збір інформації про нього;

2) розроблення плану викрадення, розподіл ролей між викрадачами, підготовка спеціальних засобів і приміщення для наступного утримання потерпілого;

3) напад і вилучення викраденої людини 3 природного мікросоціального середовища (захоплення);

4) переміщення викраденої людини до місця постійного або тимчасового утримання;

5) утримання викраденої людини (як правило, у спеціально підготовленому для цього приміщенні);

6) пред'явлення вимог близьким потерпілого (або йому самому), які є необхідною умовою для його звільнення;

7) одержання викупу і звільнення викраденої особи (якщо викрадення було вчинене з метою одержання викупу);

8) приховування слідів злочину.

Визначаючи час і місце викрадення людини та вибираючи конкретний спосіб захоплення і переміщення, злочинці враховують:

- специфіку особистості обраної жертви (фізичні особливості, довірливість, обережність, комунікабельність, а також інші риси, що впливають на характер поведінки людини);

- характеристику способу іï життя (маршрути найбільш частого переміщення i найбільш часті місця, де «об'єкт викрадення» проводить час, звичайний час виходу з будинку і повернення додому, інші обставини способу життя, які можуть полегшити або, навпаки, ускладнити викрадення);

- можливість виникнення в кожному конкретному випадку непередбачених обставин (випадкова поява сторонніх осіб і їхнє втручання в дії злочинців, випадкові несправності технічних засобів та інші обставини, що можуть ускладнити або змінити реалізацію їхнього задуму). 
Спосіб захоплення багато в чому визначається характеристикою місця, де він проводиться. Важливим чинником вибору способу захоплення також є індивідуальні особливості потерпілого (у тому числі й фізичні)

Захоплення особи за місцем роботи (наприклад, в офісі фірми) відбувається найчастіше за відсутності в ньому охоронців або в тому випадку, коли чисельність, ступінь озброєності або інші чинники дозволяють нейтралізувати (попередити) опір охорони. Одним із таких чинників може виступати, наприклад, попередня змова між одним із членів злочинної групи і кимнебудь з охоронців.

Одним зі способів викрадення людей також є обман. Його мета полягає в тому, щоб забезпечити появу жертви у певному, безпечному для злочинців місці. Подібним способом викрадення людей було вчинено у $23 \%$ випадків.

Як правило, викрадена особа доставляється до місця утримання вже на іншому, зміненому автомобілі. При цьому найчастіше безпосередні виконавці, які здійснювали викрадення жертви, не знають, де вона буде утримуватись, щоб у разі їх арешту вони не могли видати правоохоронним органам їі місцезнаходження.

У процесі переміщення злочинці для забезпечення власної безпеки жертву іноді приводять у безпорадний стан за допомогою наркотиків, алкоголю, лікарських препаратів (3\% випадків).

Основна лінія поведінки для примушування потерпілих до вчинення тих або інших дій здебільшого визначається зібраною злочинцями інформацією про особу жертви злочинного посягання, її оточення, спосіб життя і реальне матеріальне становище тощо.

Аналіз кримінальних проваджень про насильницьке зникнення показав, що для впливу на жертву злочинці завжди використовують методи психічного і фізичного насильства. До найбільш поширених належать:

- висловлення на адресу жертв і близьких їм людей погроз убивством, заподіяння тілесних ушкоджень, знищення майна, поширення компрометуючих відомостей (у 89\%). Дуже часто для більшого залякування жертви злочинці супроводжують психічне насильство демонстрацією зброї i різних предметів, пристосованих для заподіяння фізичної шкоди. В одних ситуаціях $(27,4 \%$ випадків) злочинці погрожували жертві холодною зброєю (ніж, кастет тощо), в інших (15,1\%) - предметами, які використовуються як спеціальні засоби залякування (сокира, праска, паяльник тощо);
- безпосереднє фізичне насильство над жертвою і близькими їй людьми (71\% випадків). Зазвичай фізичне насильство має дуже жорстокий характер [11, с. 28], наприклад: застосовування катування у вигляді підвішування за ноги, припікання тіла різними предметами, позбавлення їжі тощо.

Вивчення матеріалів кримінальних проваджень про насильницьке зникнення людей показало, що у 75\% випадків вимоги пред'являлися потерпілому, у 15\% - його рідним і близьким, 10\% - компаньйонам по бізнесу.

За даними Ю. М. Чорноус, у 26\% кримінальних провадженнях про злочини міжнародного характеру дії з підготовки, вчинення та приховування даних злочинів були вчинені на території України. Однак більша частина 3 них (74\%) реалізована на теритоpiї кількох держав [1, с. 106]. Наведені дані $є$ узагальненими, адже часто діяльність із вчинення злочину міжнародного характеру є досить складною, пов'язана з реалізацією заплутаних злочинних схем діяльності різних співучасників.

\section{Висновки}

Таким чином, виділення етапів насильницького зникнення людини у криміналістичному аспекті має важливе значення, тому що кожен з цих етапів й різне їх сполучення мають якісні та кількісні ознаки, що забезпечують розробку і вибір прийомів, засобів і методів, спрямованих не тільки на виявлення й розслідування цих злочинів, але й запобігання їм. Знання і розуміння етапів учинення таких злочинів дозволяють встановити обставини їх вчинення, коло причетних до їх вчинення осіб, залишені сліди тощо.

\section{Список використаних джерел:}

1. Чорноус Ю. М. Криміналістичне забезпечення досудового слідства у справах про злочини міжнародного характеру : дис. ... докт. юрид. наук: 12.00.09. Київ, 2013. 556 с.

2. Науково-практичний коментар Кримінального кодексу України / за заг. ред. О. М. Джужі, А. В. Савченка, В. В. Чернєя. 2-ге вид., перероб. і допов. Київ: Юрінком Інтер, 2018. 1104 с.

3. Науково-практичний коментар Кримінального кодексу України / за ред. М. І. Мельника, М. І. Хавронюка. Київ: ВД «Дакор», 2018. 1368 с.

4. Шинкарьов Ю. В. Арешт як вид кримінального покарання та особливості правового регулювання його виконання та відбування : автореф. дис. ... канд. юрид. наук: 12.00.08. Львів, 2007. $19 \mathrm{c}$.

5. Фулей Т. І. Застосування практики Європейського суду з прав людини при здійсненні правосуддя : наук.-метод. посіб. для суддів. 2-е вид. випр., допов. Київ, 2015. 208 с. 
6. Солдатський В. В. «Фактичне затримання» як засіб обчислення моменту затримання у кримінальному процесі. Актуальні проблеми держави $і$ права. 2012. Вип. 64. С. 524-531.

7. Кримінальний процесуальний кодекс України : Закон України від 13 квітня 2012 р. / Верховна Рада України. URL: http://zakon3.rada.gov.ua/ laws/show/4651-17 (дата звернення: 07.07.2020).

8. Шульга О. В. Затримання уповноваженою службовою особою у кримінальному прова- дженні : дис. ... канд. юрид. наук: 12.00.09. Київ: Нац. акад. внутр. справ, 2016. 255 с.

9. Конституція України : Закон від 28 червня 1996 р. № 254к/96-BP. Верховна Рада України. URL: http://zakon2.rada.gov.ua/laws/show/254\%D0\%BA/ 96-\%D0\%B2\%D1\%80 (дата звернення: 07.07.2020).

10. Расследование похищения человека метод. пособ. / А. И. Дворкин, Ю. М. Самойлов, В. Н. Исаенко, А. Ш. Ризаев. Москва: Приоритет, 2000. $112 \mathrm{c}$.

Yevhen Voitovych. Method of committing criminal offenses related to the forced disappearance of a person

The article reveals the ways of committing the enforced disappearance of a person as a multi-stage criminal operation. It is substantiated that the methods of committing acts aimed at forcible seizure of a person are quite diverse and include preparatory measures for the crime, actions of accomplices during the seizure, immediately after it and in the process of subsequent detention of the victim, as well as hiding traces of the crime. The implementation of each subsequent stage is subject to a certain sequence and a single goal, the content of which is expressed in the requirements of criminals. Typical models of the method of enforced disappearance of a person have been identified, which consists of the following stages: search for the "object of abduction" and collection of information about it; development of a plan of disappearance, distribution of roles between kidnappers, preparation of special means and premises for the subsequent maintenance of the victim; attack and removal of the stolen from the natural microsocial environment (capture); moving him to a place of permanent or temporary detention; keeping the stolen (usually in a specially prepared room); making demands on the relatives of the victim (or himself), which are a necessary condition for his release; receiving a ransom and releasing the abducted (if the abduction was committed for ransom); hiding traces of the crime. It is emphasized that deprivation of liberty in any form, ie violation of a person's right to liberty and security of person, is a mandatory element of enforced disappearance. Violation of this right, as an integral part of the crime of enforced disappearance, is the least controversial compared to, for example, the violation of the right not to be subjected to torture or other inhuman treatment. It is concluded that the selection of stages of enforced disappearance of a person in the forensic aspect is important, because each of these stages and their various combinations have qualitative and quantitative features that ensure the development and selection of techniques, tools and methods aimed not only at identifying and investigation, but also prevention of these crimes. Knowledge and understanding of the stages of committing such crimes allow to establish the circumstances of their commission, the circle of persons involved in their commission, the traces left, and so on.

Key words: method of commission, pre-trial investigation, assault, seizure, concealment. 